International Journal of Humanities and Social Sciences.

ISSN 2250-3226 Volume 11, Number 1 (2021), pp. 1-6

(C) Research India Publications

https://dx.doi.org/10.37622/IJHSS/11.1.2021.1-6

\title{
Quality of Life of Women and Family Planning
}

\author{
Hiba Thanzeeha
}

\begin{abstract}
"We two, our two" is the slogan used to promote two child policies indicating more children will lead to poverty. Government policies are encouraging twochild norm for families and many mothers are undergoing abortion and forceful sterilization to restrict the number of children to two. The quality of life of mothers who have more than three children is analyzed in the study. The sociodemographic profile of respondents, quality of care given to children are correlated with the quality of respondents in the study.Women in the age group 40-60 were taken for the study.Convenient Sampling method was chosen to conduct the study in Kerala and the sampling size was 60.Majority of respondents had the provision to provide sufficient living facilities, quality education, nutritious food $\&$ quality health care $\&$ transport facility for children. Over 93 percent respondents had good quality of life in which physical,psychological,social and environmental wellbeing were assessed.They considered family planning as the concept of having children to prepare them as human resources for the nation. Women who enjoyed social interactions and maternal benefits had good quality of life.Widowed and seperated women should be empowered to lead a life with dignity.
\end{abstract}

Keywords :Women, Quality of life \& family planning

\section{INTRODUCTION}

The study analyses the theories that has led to frame policies in national level in India and global level regarding family planning. The study analyses whether the concept of family planning to restrict the number of children in a family to 2 or 1 has to be redefined as countries that had restricted to control the birth of children are now encouraging to have more number of children. The study seeks to understand whether having more than 3 children act as a barrier for empowerment of women, their 
education and health. The religious perspectives on family planning has to be analysed to understand the family planning perspective of women and her quality of life

\section{CONCEPTUAL ANALYSIS}

Thomas Robert Malthus was the first economist to propose a systematic theory of population. He articulated his views regarding population in his famous book, Essay on the Principle of Population (1798), for which he collected empirical data to support his thesis. Malthus had the second edition of his book published in 1803, in which he modified some of his views from the first edition, but essentially his original thesis did not change.

In Essay on the Principle of Population, Malthus proposes the principle that human populations grow exponentially (i.e., doubling with each cycle) while food production grows at an arithmetic rate (i.e. by the repeated addition of a uniform increment in each uniform interval of time). Thus, while food output was likely to increase in a series of twenty-five year intervals in the arithmetic progression 1, 2, 3, 4, 5, 6, 7, 8, 9, and so on, population was capable of increasing in the geometric progression 1, 2, 4, 8, 16, 32, $64,128,256$, and so forth. This scenario of arithmetic food growth with simultaneous geometric human population growth predicted a future when humans would have no resources to survive on. To avoid such a catastrophe, Malthus urged controls on population growth

1n 1966, Singapore government implemented policies to restrict the number of children to two with the fear of increasing population and in 1987 promoted pro-natal policies to encourage having more children as the government realized the need for human resources in the country.

Five factors played a direct role in the transition of India's population policy from target-oriented to target-free. The five factors were: (1) the research of Indian academics; (2) the work of women's health advocates; (3) the support of the officials who approved the target-free approach; (4) the influence of the donors to India's family welfare programme, especially the World Bank; and (5) the United Nations sponsored International Conference on Population and Development.(Donaldson,2002).

The Law Reforms Commission of Kerala headed by eminent jurist Justice V R Krishna Iyer has recommended a penalty of Rs 10,000 and withdrawal of free education and health care for anyone who goes for a third child. Clause 7 of the Bill reads, "No person or institution shall use religion, region, sect, caste, cult or other inducements for production of more children than permitted." Once the law comes into force, "Any person or a public organization or institution associated with or carrying on the work of family planning and birth control" may approach a court against those found violating the provisions. (Times of India,2008)As well as free contraception, education and family planning, the state government here has tried to equalise men and women to lower the fertility rate. Compared to the rest of India, Kerala has a lower infant mortality rate of 6.70 compared to 44.0 (2009) (Langworthy, 2013) The policy makers guessed 
that the excessive family size (around 5 children per couple in 1974)was responsible for poverty and announced cash incentives for those who are willing to be sterilised, Commissions for health workers, proposal to only allow people with two or less children to run for public were some of the measures adopted by government for family planning

In modern Hindus, it stands to reason that the stability of social order necessitates the adoption of the small-family norm, and dharma includes the notion of public duty and public responsibility. Hence the small-family norm, achievable through contraception and family planning methods, is entirely consistent with and in no way opposed to the Hindu concept of dharma. This concept of family planning is backed by a broad social consensus (Sandhya Jain,2013).

Family planning should be left up to Christian parents, as they seek the Lord's guidance in making the decision. It is wrong, therefore, for government entities, employers, or any others to dictate the number of children a couple may have. The parents have the primary responsibility in bringing up children, and neither the government nor any other party should have any say. ( Elise Newcomer,2013).

Allah says in the Glorious Qur'an “...Kill not your children on a plea of want; We provide sustenance for you and for them;" (Al-Qur'an 6:151)Kill not your children for fear of want: We shall provide sustenance for them as well as for you: verily the killing of them is a great sin." (Al-Qur'an 17:31)However, scholars unanimously agree that any permanent method of family planning, or even abortion, can be done if the life of the mother is in danger. For e.g. if the woman is suffering from certain diseases like heart disease or has under gone multiple caesarean operations and in her case the continuation of pregnancy or another pregnancy may be detrimental to her life, then the woman can be aborted or a permanent method of family planning can be adopted to save the life of the woman. Coitus Interruptus is permissible as long as it is performed with mutual consent of both the husband and wife since both of them have equal right to have children. Allah has provided a natural method of planning the family, which is medically known as lactation amenorrhea. After the women gives birth to a child, till she breast feeds she does not have her menstrual cycle, thus the chances of pregnancy in this period of lactation is minimal. Allah says in the Qur'an "The mothers shall give suck to their offspring for two whole years..." (Al-Qur'an 2:233).

With regards to the claim of the people who say that the growth in population increases poverty, this was mainly based on Malthusian's theory. This theory states that, to maintain prosperity and welfare of human race, its increase should be checked to correspond with the production of foodstuff.

But now we have realized that Malthusian's theory has been proved wrong and there is no shortage of food grains. Moreover, in spite of the amount of land India uses in agriculture, there is still much more land in India, which can, with little more efforts in fertilizing it through the proper means be utilized in agriculture thus producing more food grains. (Dr.Zakir Naik, 2010) 


\section{METHODS}

Descriptive Research design is selected to conduct the research as the research describes all the aspects regarding the quality of life of women who have more than three children

Self -prepared Questionnaire was used to study the socio-demographic profile of respondents and quality of care given to children to analyse its relationship with quality of life.The physical health,psychological health,social wellbeing and quality of environment the respondent resides in are measured with quality of life scale prepared by WHO.Convenient sampling method is selected to choose the respondents.60 respondents are chosen to conduct the study. Women in age group 4060 who have more than 3 children was taken for the study.

\section{FINDINGS}

Majority of respondents were Muslims. Only 3percent of respondents were Hindus and 9 percent of respondents were Christians Only 28 percent respondents were involved in educational programme and majority of respondents were not involved in any educational programmMajority of respondents had 4 children.Majority of respondents $(83.3 \%)$ felt that children are a blessing for their family and society. Only few respondents $(8 \%)$ have felt that their children are burden for their family and society and majority of respondents felt that chidren are not at all burden for their family. There was significant positive correlation between the economic status of respondents, quality of care given to children, involvement in social welfare with the quality of life of respondents. The cross tabulation between education and quality of life has shown that who have completed high school, graduation and post graduation have good quality of life. Majority of respondents had adequate income.Majority of respondents (77\%)own property The respondents who were not able to fulfill their aspirations faced poor mental health eventhough they do not face any financial crisis. The respondents who were separated from their husband due to drug addiction and widowed worked hard for earning income and are able to enjoy their life. Majority of respondents (93\%) have the provision to provide sufficient living facilities, quality education, nutritious food \& quality health care \& transport facility for children. Over 57 percent respondents are satisfied and 30 percent are very satisfied in guiding their children morally. The respondents who are dissatisfied in guiding children morally are 12 percent. The overall quality of life is good for 41 percent respondents and very good for 37 percent respondents. Only 7 percent respondents has responded that their quality of life is poor

\section{DISCUSSION}

The findings of the study motivates to think whether government policies to restrict the number of children to two should be changed as the present BJP government is discussing about promoting anti-natal policy.Demographic dividend is optimistically looked upon as countries like Singapore transformed their family planning policy to encourage having more than two children from the policies to restrict the number of children a family should have to two. One of India's competitive advantages is its 
demographic dividend. Demographic dividend occurs when the proportion of working people in the total population is high because this indicates that more people have the potential to be productive and contribute to growth of the economy. According to the United National population research, during the last four decades the countries of Asia and Latin America have been the main beneficiaries of the demographic dividend. Advanced countries of Europe, Japan and USA have an ageing population because of low birth rates and low mortality rates. Neither the least developed countries nor the countries of Africa have as yet experienced favourable demographic conditions according to the research by UN population division. China's one child policy has reversed the demographic dividend it enjoyed since the mid 1960s according to a World Bank global development report.

Falling birth rates reduce the overall expenditure required to provide basic necessities for the under 14 age group (which is yet to be productive) and increased longevity ensures that a large proportion of the population are within the 15-59 age group (working population). Dependency ratio refers to the proportion of non -working poplation on the working population. In India this ratio is around 0.6 according to the World Bank.

However, reaping the demographic dividend requires focused policy action. A recent UNESCAP survey warns there are no guarantees the "dividend" will automatically translate to economic growth. Countries need to put in place the appropriate "social and economic policies and institutions" to absorb the rapidly growing labour force. Reforms in the health and education sector, financial inclusion and adequate employment opportunities are essential pre-requisites to ensure that India's young population is truly an asset.(Balaram,2011)Government policies should not force the couples to restrict the number of children to two instead should support the family that need support for education and health. Vocational training programmes should be organised for women who wanted employment.

Online facilities can be used for women who wanted to pursue higher education as the comparison between quality of life and education has shown that those who had poor quality of life had education below high school.

Maternity benefit act should be modified to ensure the health of child and mother as only 6 months leave will motivate women to avoid breast feeding which will worsly effect the health of child,.Government policies should not force the couples to restrict the number of children to two instead should support the family that need support for education and health.

Government should provide financial resources for widowed women as they are burdened with household work and work outside home.

Drug addiction Is bane for the society as the respondents whose husbands are addicted to drugs have poor quality of life. 


\section{CONCLUSION}

Women who were able to enjoy the spousal support for maternal benefits and social interactions had good quality of life. The desire to work more and prepare their children as human resources to the nation is the concept of family planning that encourages having children. Countries like France and Singapore promotes to have more number of children so that nation gets human resources after making policies to restrict the number of children to two. Women should get support from family and community to study after marriage and online facilities should be utilised with regard to pursue higher education and employmemt . Widowed women feels their children as assets even though they face financial difficulties. Separated and widowed women have to be supported by family and society by empowering them to live with dignity.

\section{REFERENCE}

[1] JASON BREMNER. (2015). BUILDING RESILIENCE THROUGH FAMILY PLANNING. Retrieved January 2016, from http://www.prb.org/: http://www.prb.org/pdf15/sahel-resilience-brief.pdf

[2] Kristen Conway, K. B. (2011, SEPTEMBER 18-9-11). POPULATION AND NATURAL RESOURCES. Retrieved JANUARY 2-2-17, 2017, from cgge.aag.org:

http://cgge.aag.org/populationandnaturalresources1e/CF_popnatres_Jan10/CF_ popnatres_Jan10.html

[3] Langworthy, M. (2013, November 15-11-13). Anti -natal Policies in India. Retrieved january 3-2-17, 2017, from prezi.com: https://prezi.com/_xem6arsvfta/anti-natal-policies-in-india/?Webgl=0

[4] Sexypandaalex. (2012, decembner 21-12-12). Case Study: Anti-Natalist Policy in Kerala. Retrieved january 3-2-17, 2017, from getrevising.co.uk: https://getrevising.co.uk/resources/case_study_anti_natalist_policy_in_kerala

[5] Thomas, K. (2007, March). Retrieved October 13, 2015, from www.cox.com: http://www.cox.com/wcm/en/aboutus/datasheet/takecharge/archives/2007-teensurvey.pdf?Campcode=takecharge-archive-link_2007-survey_0511

[6] Wong, T. (2003, June 20-6-11). Fertility and the Family:An Overview of Pronatalist Population Policies in Singapore. Retrieved January 2-2-17, 2017, from www.populationasia.org:

http://www.populationasia.org/Publications/RP/AMCRP12.pd 